\title{
A Study on Optimization of Fish Protein Hydrolysate Preparation by Enzymatic Hydrolysis from Tilapia Fish Waste Mince
}

\author{
A. Srikanya ${ }^{1}$, K. Dhanapal ${ }^{1 *}$, K. Sravani ${ }^{1}$, K. Madhavi $^{2}$ and G. Praveen Kumar ${ }^{1}$ \\ ${ }^{1}$ Department of Fish Processing Technology, ${ }^{2}$ Department of Aquatic Environment Management, \\ College of Fishery Science, Muthukur, Nellore District, Andhra Pradesh, India \\ *Corresponding author
}

\section{A B S T R A C T}

Fish industry is a major economic source for a number of countries worldwide. The fish

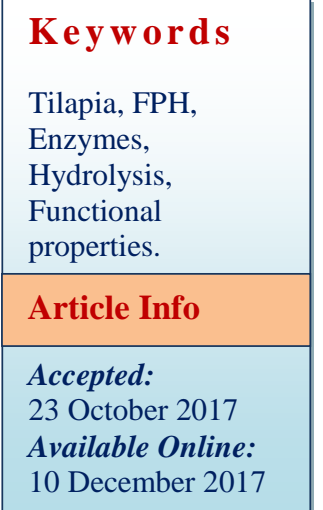
processing industry produces more than $60 \%$ as waste, which include head, skin, trimmings, fins, frames, viscera and roes. So, the aim of the present study is to convert fish processing wastes from tilapia into protein hydrolysate using papain enzyme. Fish Protein Hydrolysates (FPH) were prepared by using Tilapia Waste Mince (TWM) by optimizing hydrolysis parameters such as enzyme to substrate ratio (E/S at $0.5,1.0,1.5$ and $2 \%$ ), temperature $\left(27,30,50\right.$ and $\left.70^{\circ} \mathrm{C}\right), \mathrm{pH}(4.0,6.5,7.0$ and 9.0) and time of hydrolysis (30, 60, 90 and 120 minutes) by standardization. The optimum conditions for hydrolysis of tilapia processing wastes were found at the $\mathrm{E} / \mathrm{S}$ ratio of $1 \%, 50^{\circ} \mathrm{C}$ temperature at $\mathrm{pH} 6.5$ for 60 minutes time of hydrolysis. Protein content, yield and functional properties of FPH at different enzyme substrate ratio were also evaluated. At $1 \% \mathrm{E} / \mathrm{S}$ ratio, the protein content was found to be $82.15 \pm 0.02 \%$ with $14.23 \pm 0.03 \%$ degree of hydrolysis and yield of $7.64 \pm 0.02 \%$. The foaming capacity, foaming stability, emulsifying capacity and emulsifying stability were found to be lower at $1 \% \mathrm{E} / \mathrm{S}$ ratio and the values were $47.17 \pm 0.58,9.17 \pm 0.58,48.24 \pm 0.02$ and $30.02 \pm 0.01$ and higher at $0.5 \% \mathrm{E} / \mathrm{S}$ ratio and the values were $52.18 \pm 0.02,13.03 \pm 0.01,53.11 \pm 0.07$ and $36.07 \pm 0.01$ respectively.

\section{Introduction}

Annual discard of fish industry is $25 \%$ of the total production that is estimated to be approximately 21.72 million tons (FAO, 2014). It is estimated that fish processing waste after filleting accounts for approximately $75 \%$ of the total fish weight. About $25 \%$ of the total weight remains as waste in the form of skins and bones during preparation of fish fillets. This waste is an excellent raw material for the preparation of high value products including protein foods. Fish waste is a good source of protein (Arnesen and Gildberg, 2006), but a huge amount of the waste is still being discarded without much effort to recover its protein (Kristinsson and Rasco, 2002). These wastes contain good amount of protein rich material that are normally processed into low marketvalue products, such as animal feed, fish meal and fertilizer (Hsu, 2010). These large quantities of fish by-product waste from fisheries would create serious pollution and disposal problems in both developed and developing countries. Fish waste can be value added by converting it into fish protein hydrolysate $(\mathrm{FPH})$ by utilizing proteolytic 
enzymes to hydrolyze the fish protein (Kristinsson and Rasco, 2000). The raw material for FPH production may be obtained from different sources like low economic value fish and fish processing waste. The use of fish meat for FPH production in large quantities will be viable only if the fish is available in abundance at low prices. Protein hydrolysates are breakdown products obtained by enzymatic conversion of proteins into smaller peptides. Generally, protein hydrolysates are small fragments of peptides that contain 2-20 amino acids.

These are produced by the enzymatic hydrolysis of native proteins. Protein hydrolysates decrease the peptide size thereby making hydrolysates, the most available amino acid source for various physiological functions of human body. Protein hydrolysates are used as readily available sources of protein for humans and animals due to their good functional properties (Neklyudov et al., 2000). Protein hydrolysates generated from fish proteins are good nutritional supplements as bioactive compounds and can be easily absorbed and utilized for various metabolic activities (Nesse et al., 2011). Protein hydrolysates obtained after hydrolysis of proteins are composed of free amino acids and short chain peptides exhibiting many advantages as nutraceutical or functional foods because of their amino acid profile. The amino acid composition of any food proteins has significant role in various physiological activities of human body and affects either directly or indirectly in maintaining good health. Fish protein hydrolysates have potential application as functional ingredients in different foods because they possess numerous important and unique properties such as water holding capacity, oil absorption capacity, protein solubility, gelling activity, foaming capacity and emulsification ability (Chalamaiah et al., 2010).
Tilapia is a popular freshwater fish with nutritional benefits and wide availability. Due to the growing demand for tilapia fillet in producing fish-based food products, large amounts of waste have been generated. This waste is usually discarded and cause numerous environmental problems (Arvanitoyannis and Kassaveti, 2008) and contain considerable amounts of proteins that are known to possess high nutritional value with respect to essential amino acid composition (Venugopal, 2008) and rich protein content (Arnesen and Gildberg, 2006) varying from $15-60 \%$ (Je et al., 2004; Jung et al., 2006; Sathivel et al., 2004). Recovery of proteins from these wastes and conversion to high value products such as bioactive peptides is a very exciting and promising alternative. In recent years, the production of bioactive peptides from fish waste has received a growing attention due to their physiological functions such as antihypertensive and antioxidative activities which are suitable for applications in healthcare and pharmaceutical products (Je et al., 2004; Jung et al., 2006). So the aim of the present study was to prepare protein hydrolysates from the tilapia processing waste using papain enzyme and evaluate the functional properties of protein hydrolysates extracted from tilapia processing wastes.

\section{Materials and Methods}

\section{Raw material for preparation of fish protein hydrolysate $(\mathrm{FPH})$}

The frame waste (FW) and head waste (HW) obtained from Tilapia (Oreochromis niloticus) were minced with meat mincer and packed in polythene bags and stored at $20 \pm 2^{\circ} \mathrm{C}$ until further use. The frame waste was used for preparation of FPH within 20 days of storage. Papain (from Carica papaya latex) was procured from Sigma Chemical Co., St. Louis, MO, USA. 


\section{Preparation of Tilapia waste mince (TWM)}

Tilapia processing wastes (TPW) contain heads and frames brought to the laboratory in iced condition were washed twice with chilled water.

The TPW were chopped in to small pieces and minced in a meat mincer (Model No. TC $12 \mathrm{R} 10 \mathrm{IX}$ ) and packed in polythene bags and stored at $-20 \pm 2^{\circ} \mathrm{C}$ until further use.

Preparation of Tilapia waste mince homogenate for hydrolysis

Tilapia fish waste mince was mixed with water in the ratio of $1: 2$ and homogenized with kitchen blender. The resultant mixture of water and mince was referred as TWM homogenate.

\section{Optimization of hydrolysis parameters}

The parameters such as enzyme to substrate ratio $(\mathrm{E} / \mathrm{S})$, temperature, $\mathrm{pH}$ and time of hydrolysis was optimized using the tilapia fish waste mince as a substrate against papain by varying one parameter at a time and keeping other parameters constant. The optimum enzyme to TWM ratio was selected for each enzyme to optimize other parameters.

\section{Preparation of protein hydrolysates from} tilapia waste mince using papain

The optimum conditions used for getting the hydrolysate were a temperature of $50^{\circ} \mathrm{C}, \mathrm{pH}$ $6.5 \pm 0.2$ and hydrolysis time of 1 hour. Papain $\mathrm{E} / \mathrm{S}$ was used to achieve desired degree of hydrolysis. The hydrolysis was terminated by keeping the reaction mixture in water bath. The slurry was filtered using Whatman No. 4 filter paper. The filtrate was dried in hot air oven at $80 \pm 2^{\circ} \mathrm{C}$ for 48 to 60 hours to achieve a final moisture content of less than $5 \%$. The dried hydrolysates were stored in desiccated condition at ambient temperature $\left(25 \pm 2{ }^{\circ} \mathrm{C}\right)$.

\section{Degree of hydrolysis}

Degree of hydrolysis was determined according to the method described by Cao et al., (2008). Degree of hydrolysis was calculated as the ratio of $\alpha$-amino nitrogen liberated from the meat and total nitrogen content of meat taken for the hydrolysis.

The $\alpha$-amino nitrogen was determined by formol titration as detailed in section 3.3.2 and total nitrogen was determined by Kjeldahl method as detailed in 3.3.1. The following formula was used to calculate the degree of hydrolysis.

$\mathrm{DH}(\%)=\frac{\text { AAN } x \text { TVS }}{\text { WM } \times 100}$

Where,

AAN - $\alpha$-amino nitrogen (mg / $\mathrm{ml}$ of supernatant); TVS - total volume of supernatant $(\mathrm{ml})$; TN - total nitrogen content (mg / $\mathrm{g}$ of mince); WM- weight of mince taken for hydrolysis $(\mathrm{g})$.

\section{Determination of Yield of fish protein hydrolysate (FPH)}

Yield was calculated as percentage ratio of weight of the meat in gram to the weight of the hydrolysates obtained in grams

Yield $(\%)=\frac{\text { Weight of the hydrolysate }}{\text { Weight of the total meat taken for hydrolysate }} \times 100$

Functional properties of fish protein
hydrolysate

\section{Determination of emulsifying capacity and stability}

The method of Yasumatsu et al., (1972) was used to determine emulsifying capacity and stability. Emulsion was prepared with $1 \mathrm{~g}$ of 
each sample with $50 \mathrm{ml}$ of cold distilled water $\left(4^{\circ} \mathrm{C}\right)$ and $50 \mathrm{ml}$ of sunflower oil.

The FPH samples were dispersed with a homogenizer/blender. Each blended sample was equally divided into $50 \mathrm{ml}$ centrifuge tubes was directly centrifuge at $4000 \times \mathrm{g}$ for 10 min while the other was centrifuged under the same conditions after heating in a water bath at $80^{\circ} \mathrm{C}$ for $30 \mathrm{~min}$. and then cooling to room temperature $\left(25^{\circ} \mathrm{C}\right)$. The height of emulsified layer, as a percentage of the total height of material in the unheated tubes, was used to calculate the emulsifying capacity and stability, using following formulae:

$$
\text { Emusifying capacity }(\%)=\frac{\text { Height of emulsion layes }}{\text { Height of whole layer }} \times 100
$$

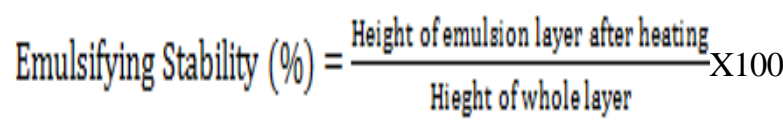

\section{Determination of foaming properties}

The method of Miller and Goninger (1976) was used to determine foaming properties. The powdered sample (1g) was added to 100 $\mathrm{ml}$ distilled water and homogenized for $1 \mathrm{~min}$. at high speed homogenizer (M/S polyton PT 2100, Swizerland). The mixture was carefully transferred in to a $250 \mathrm{ml}$ calibrated beaker for volume measurement.

The foam was calculated as the volume of mixture after blending compared to the original volume. The foaming stability was the ratio of the foaming capacity after $30 \mathrm{~min}$. divided by the original foam capacity.

\section{Statistical analysis}

The results were expressed as mean \pm Standard Deviation (SD). The correlation coefficients between the parameters were carried out using the same software. The Statistical Package for Social Sciences (SPSS
20) statistical package was used for analysis of the experimental results. Sufficient number of samples was carried out for each analysis.

\section{Results and Discussion}

\section{Proximate Composition of head waste (HW) and frame waste (FW) from Tilapia (Oreochromis niloticus) used for preparation of fish protein hydrolysate}

Proximate composition of Tilapia waste (TW) including HW and FW are presented in Table 1. From the results it was observed that tilapia waste contain $14.93 \pm 0.3 \%$ crude protein, $66.29 \pm 0.2 \%$ moisture, $4.51 \pm 0.3 \%$ fat and $8.6 \pm 0.04 \%$ ash. Several studies have shown that the crude protein content of fish byproducts varies from 8 to $35 \%$.

The crude protein content of tilapia waste was also within this range, indicating that it possess considerable amount of protein.

The moisture content of tilapia waste was in agreement with results obtained by several authors for catfish frame (Amiza et al., 2011), salmon skin (See et al., 2011), catla visceral waste (Bhaskar et al., 2008) and Alaska pollock (Hou et al., 2011). Relatively low fat content was observed in tilapia waste $(4.51 \%)$ compared with other fish waste such as catla visceral waste which is $12.8 \%$ (Bhaskar et al., 2008).

Tilapia waste showed relatively higher ash content $(8.6 \%)$ when compared with other fish waste such as cod head (Arnesen and Gildberg, 2006), catfish frame (Amiza et al., 2011) and catla visceral waste (Bhaskar et al., 2008) which are 6.8, 7.08 and $2.50 \%$ respectively, but had lower ash content compared with Alaska pollock frame which is $14.99 \%$ (Hou et al., 2011). High ash content is largely contributed by bones in every part of tilapia waste including head and frame (Batista et al., 2010). 


\section{Proximate composition of optimized FPH}

Proximate composition of FPH prepared from TW (Table 1) and the results showed that protein is the major component, followed by ash, moisture and fat with values of $82.19 \pm 0.02 \%, 11.06 \pm 0.02 \%, 5.04 \pm 0.03 \%$ and $0.58 \pm 0.02 \%$ respectively.

Protein content of the prepared FPH was similar with hydrolysates from other fish byproducts, such as tilapia meat hydrolysate (Foh et al., 2011), and catfish frame (Amiza et al., 2011).

High protein content of FPH demonstrates its potential use as protein supplements for human nutrition.

The fat content of various fish protein hydrolysates was below 5\% (Ovissipour et al., 2009; Bhaskar et al., 2008). Only few studies reported that the fat content was above 5\% level for FPH (Chalamaiah et al., 2010; Souissi et al., 2007). In the present study, lower FPH fat content was due to the removal of the fat layer after hydrolysis.

The ash content of fish protein hydrolysates has been reported in the range of $0.45-27 \%$ of total composition (Benjakul and Morrissey, 1997; Bhaskar et al., 2008). In the present study, the ash content of FPH was within the range indicated and the relatively high ash content might be due to the addition of sodium phosphate buffer during enzymatic processing (Benjakul and Morrissey, 1997; See et al., 2011).

Most studies have demonstrated that the protein hydrolysates from various fishes contain moisture <10\% (Wasswa et al., 2007; Bhaskar et al., 2008; Chalamaiah et al., 2010). In the present study, the FPH moisture content was $5.04 \pm 0.03 \%$ which is in agreement with Bueno-Solano et al., (2009).

\section{Yield of FPH}

The yield of FPH from tilapia waste varied from 5.05 to $7.81 \%$ at different parameters as shown in Table 2. The results were in agreement with Gajana et al., (2016) who stated that the yield of FPH varied from 4.67 to $9.46 \%$ and also Tanuja et al., (2012) where striped catfish frame FPH was prepared using papain and bromelain showed yield in the range of 5-6\% for different hydrolysates at different degree of hydrolysis. The yield of FPH obtained in the present study was lower compared to the typical yields reported from Mugil cephalus (10-15\%) studied by Rebaca et al., (1991) which may be due to the lower degree of hydrolysis and nature of the substrate used. Yield of hydrolysates from catla were $6.60,8.76,5.44$ and $10.40 \%$ for alcalase, bromelain, flavorzyme and protamex respectively (Elavarasan et al., 2014).

\section{Functional properties of FPH}

Functional properties of hydrolysates prepared from tilapia waste using papain were analyzed as a function of protein concentration and degree of hydrolysis. The protein concentrations studied at different $\mathrm{E} / \mathrm{S}$ ratios were $0.5,1.0,1.5$, and $2 \%(\mathrm{w} / \mathrm{w})$. Functional properties are related to the sequence and composition of amino acids, molecular weights, conformation and charge distribution (Lempek et al., 2007).

\section{Emulsifying properties (Emulsion Activity Index and Emulsion Stability Index)}

The emulsifying properties of FPH samples decreased with increase in degree of hydrolysis (Table 3). Emulsifying properties are highly dependent on the structure of derived peptides, distribution of hydrophilic and hydrophobic amino acid residues in the sequence and the size of peptides Gajanan $e t$ al., (2016). 
Fig.1 Preparation of protein hydrolysates

Addition of distilled water (Meat: water 1:2)

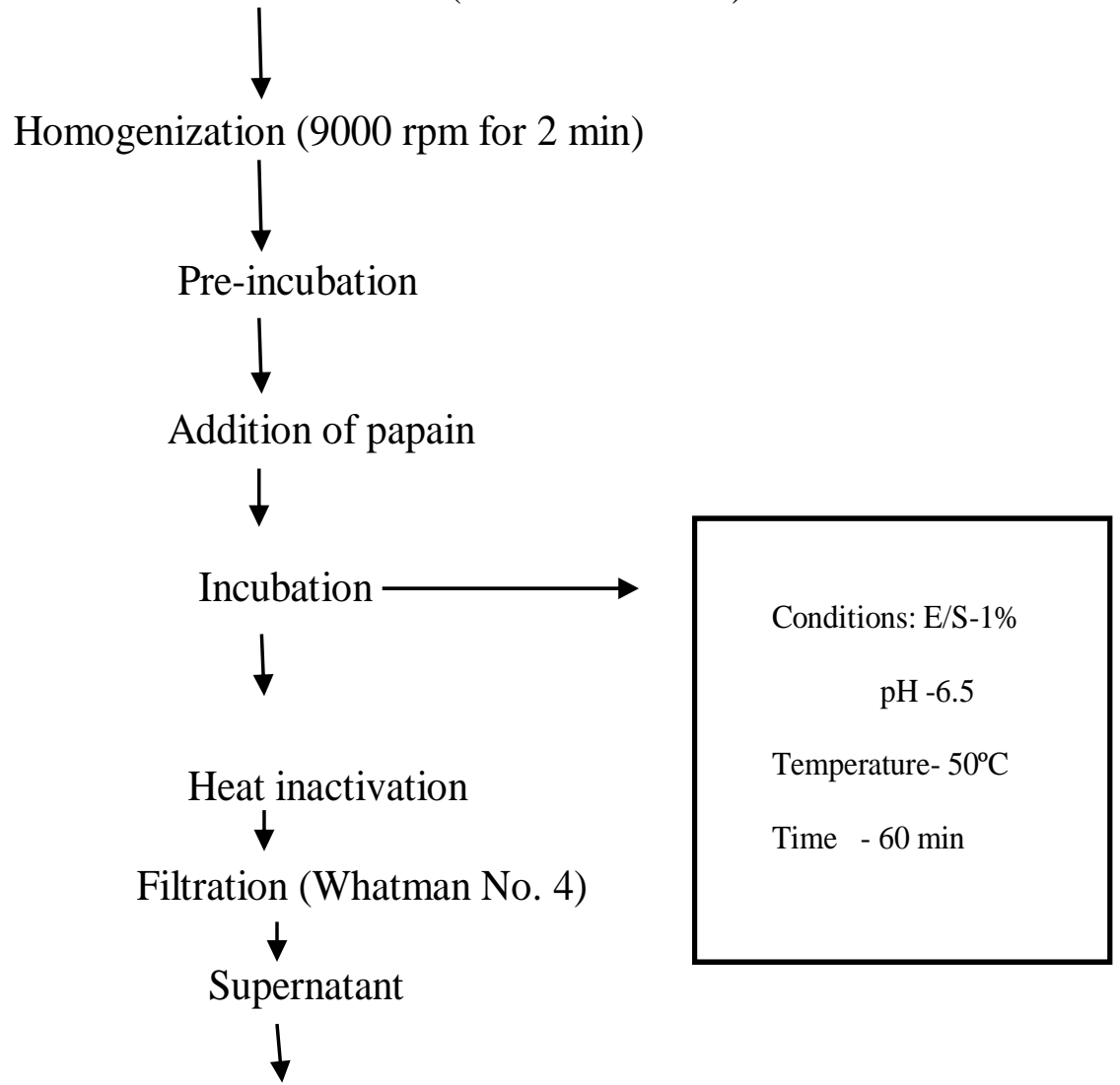

Drying in hot air oven $\left(80 \pm 2^{\circ} \mathrm{C}\right)$

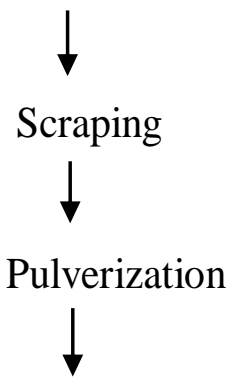

Stored in the glass vials in air tight condition

Table.1 Proximate composition of Tilapia waste and Fish protein hydrolysate

\begin{tabular}{|l|l|l|l|}
\hline S.NO & Percentage & Tilapia waste & Fish protein hydrolysate \\
\hline 1 & Moisture & $66.29 \pm 0.2$ & $5.04 \pm 0.03$ \\
\hline 2 & Protein & $14.93 \pm 0.3$ & $82.19 \pm 0.02$ \\
\hline 3 & Fat & $4.51 \pm 0.3$ & $0.58 \pm 0.02$ \\
\hline 4 & Ash & $8.6 \pm 0.04$ & $11.06 \pm 0.02$ \\
\hline
\end{tabular}


Table.2 Optimization of hydrolysis parameters for the preparation of frame waste hydrolysate obtained using papain

\begin{tabular}{|c|l|l|l|l|}
\hline \multicolumn{2}{|c|}{ Parameters } & Protein (\%) & DH (\%) & Yield (\%) \\
\hline \multirow{3}{*}{ Temperature $(\mathbf{C})$} & 27 & $80.73 \pm 0.07$ & $13.32 \pm 0.5$ & $6.50 \pm 0.3$ \\
\cline { 2 - 5 } & 30 & $82.07 \pm 0.06$ & $14.20 \pm 0.2$ & $6.90 \pm 0.01$ \\
\cline { 2 - 5 } & $\mathbf{5 0}$ & $\mathbf{8 2 . 1 0} \pm \mathbf{0 . 0 2}$ & $\mathbf{1 4 . 5 0} \pm \mathbf{0 . 0 3}$ & $\mathbf{7 . 2 5} \pm \mathbf{0 . 0 1}$ \\
\cline { 2 - 5 } & 70 & $80.95 \pm 0.02$ & $13.26 \pm 0.01$ & $7.30 \pm 0.01$ \\
\hline \multirow{4}{*}{$\mathbf{p H}$} & 4 & $67.11 \pm 0.01$ & $8.55 \pm 0.01$ & $5.71 \pm 0.01$ \\
\cline { 2 - 5 } & $\mathbf{6 . 5}$ & $\mathbf{8 2 . 0 7} \pm \mathbf{0 . 0 1}$ & $\mathbf{1 4 . 1 6} \pm \mathbf{0 . 0 2}$ & $\mathbf{7 . 1 1} \pm \mathbf{0 . 0 1}$ \\
\cline { 2 - 5 } & 7 & $76.54 \pm 0.02$ & $11.54 \pm 0.02$ & $5.90 \pm 0.01$ \\
\cline { 2 - 5 } Time (min) & 9 & $72.86 \pm 0.02$ & $10.57 \pm 0.01$ & $5.05 \pm 0.01$ \\
\hline \multirow{3}{*}{ E/S (\%) } & 30 & $82.05 \pm 0.01$ & $14.14 \pm 0.02$ & $6.9 \pm 0.02$ \\
\cline { 2 - 5 } & $\mathbf{6 0}$ & $\mathbf{8 2 . 2 1} \pm \mathbf{0 . 0 1}$ & $\mathbf{1 4 . 4 3} \pm \mathbf{0 . 0 1}$ & $\mathbf{7 . 8 1} \pm \mathbf{0 . 0 1}$ \\
\cline { 2 - 5 } & 90 & $82.32 \pm 0.02$ & $14.74 \pm 0.01$ & $6.8 \pm 0.05$ \\
\cline { 2 - 5 } & 120 & $82.53 \pm 0.02$ & $14.85 \pm 0.01$ & $7.04 \pm 0.01$ \\
\hline & 0.5 & $67.35 \pm 0.03$ & $8.72 \pm 0.01$ & $5.90 \pm 0.02$ \\
\cline { 2 - 5 } & $\mathbf{1 . 0}$ & $\mathbf{8 2 . 1 5} \pm \mathbf{0 . 0 2}$ & $\mathbf{1 4 . 2 3} \pm \mathbf{0 . 0 3}$ & $\mathbf{7 . 6 4} \pm \mathbf{0 . 0 2}$ \\
\cline { 2 - 5 } & 1.5 & $82.35 \pm 0.02$ & $14.76 \pm 0.02$ & $6.94 \pm 0.03$ \\
\cline { 2 - 5 } & 2.0 & $82.58 \pm 0.01$ & $14.83 \pm 0.01$ & $6.16 \pm 0.01$ \\
\hline
\end{tabular}

Table.3 Functional properties of FPH

\begin{tabular}{|l|l|l|l|l|}
\hline Properties (\%) & $\mathbf{0 . 5 \%}$ E/S & $\mathbf{1 . 0 \%} / \mathbf{S}$ & $\mathbf{1 . 5 \%}$ E/S & $\mathbf{2 . 0 \%}$ E/S \\
\hline Foaming capacity & $52.18 \pm 0.02$ & $47.17 \pm 0.58$ & $51.72 \pm 0.02$ & $49.04 \pm 0.02$ \\
\hline Foaming stability & $13.03 \pm 0.01$ & $9.17 \pm 0.58$ & $11.02 \pm 0.03$ & $9.88 \pm 0.01$ \\
\hline Emulsifying capacity & $53.11 \pm 0.07$ & $48.24 \pm 0.02$ & $50.90 \pm 0.02$ & $51.03 \pm 0.02$ \\
\hline Emulsifying stability & $36.07 \pm 0.01$ & $30.02 \pm 0.01$ & $31.43 \pm 0.11$ & $32.03 \pm 0.01$ \\
\hline
\end{tabular}

From the results it was observed that FPH prepared from tilapia waste had emulsifying capacity of $48.24 \%$ at $1 \% \mathrm{E} / \mathrm{S}$ (Table 3) which are in agreement with the results of Elavarasan and Shamasudar (2013).

\section{Foaming properties (Foaming capacity and Foam stability)}

The relation between the degree of hydrolysis and the foaming capacity and foam stability were inversely proportional (Table 3 ). In the present study, the foaming capacity of FPH prepared from tilapia wastes was $47.17 \%$ at $1 \% \mathrm{E} / \mathrm{S}$ ratio. The results of this study were in agreement with the reports of Gajanan et al.,
(2016) where foaming capacity of $30-40 \%$ was obtained at $15 \%$ degree of hydrolysis. There is a relation between the degree of hydrolysis and foaming properties (Kristinsson and Rasco, 2000). Foam stability depends on the extent of protein-protein interaction within the matrix.

The foam stability of FPH prepared from tilapia $(9.17 \%$ at $1 \% \mathrm{E} / \mathrm{S}$ ratio) was lower than the values of Elvarasan et al., (2014) where foam stability was $15 \%$ with papain enzyme. The differences in foaming capacity and foam stability of hydrolysate prepared using different enzymes may be attributed to different charge and size of the peptides 
produced by different enzymes (Naqash and Nazeer, 2013).

The high moisture content in fishery waste make them more perishable and may cause undesirable effects to environment pollution as well as requires high cost in managing waste disposal. Production of fish protein hydrolysates is one way to add value to proteinaceous fish waste. From the results, it was demonstrated that hydrolysates produced had good functional properties indicating their possible use in different food systems. However, further research including real food systems is recommended. The use of commercial enzymes for production of highly functional hydrolysates from low commercial value can be a fish feasible technology to make the most of the vast underutilized resources and use it as a food ingredient for direct human consumption.

\section{Acknowledgement}

The authors would like to thank the Vice Chancellor of Sri Venkateswara Veterinary University (SVVU), Tirupati, Dean of Fishery Science, SVVU, Tirupati and Associate Dean, College of Fishery science, SVVU, Muthukur for providing facility and support.

\section{References}

Amiza, M.A., Nurul Ashikin, S. and Faazaz, A.L. 2011. Optimization of Enzymatic Protein Hydrolysis from Silver Catfish (Pangasius sp.) Frame and Biological Characteristics of Protein Hydrolysates from Fermented Shrimp by-Products. Food Chemistry, 112: 671-675.

Arnesen, J. A. and Gildberg, A. 2006. Extraction of muscle proteins and gelatine from cod head. Process Biochemistry, 41(3): 697-700.

Arvanitoyannis, I. S. and Kassaveti, A. 2008. Fish industry waste: treatments, environmental impacts, current and potential uses. International Journal of Food Science and Technology, 43(4): 726-745.

Batista, I., Ramos, C., Coutinho, J., Bandarra, N. M. and Nunes, M. L. 2010. Characterization of protein hydrolysates and lipids obtained from black scabbard fish (Aphanopus carbo) by-products and antioxidative activity of the hydrolysates produced. Process Biochemistry, 45(1): 18-24.

Benjakul, S. and Morrissey, M. T. 1997. Protein hydrolysates from Pacific whiting solid wastes. Journal of Agricultural and Food Chemistry, 45(9): 3423-3430.

Bhaskar, N. and Mahendrakar, N. S. 2008. Protein hydrolysate from visceral waste proteins of Catla (Catla catla): Optimization of hydrolysis conditions for a commercial neutral protease. Bioresource Technology, 99(10): 41054111.

Bueno-Solano, C., Lopez- Cervantes, J., Campas-Baypoli, O.N., LauterioGarcia, R., Adan-Bante, N.P. and Sanchez-Machado, D.I. 2009.Chemical and Biological characteristics of protein hydrolysates from fermented shrimp by products. Food chemistry, 112: 671675.

Cao, W., Zhang, C., Hong, P. and Ji, H., 2008. Response surface methodology for autolysis parameters optimization of shrimp head and amino acids released during autolysis. Food Chemistry, 109: 176-183.

Chalamaiah, M., Narsing Rao, G., Rao, D. G. and Jyothirmayi, T. 2010. Protein hydrolysates from meriga (Cirrhinus mrigala) egg and evaluation of their functional properties. Food Chemistry, 120: 652-657.

Elavarasan, K. and Shamasundar, B.A. 2013. Angiotensin I-converting enzyme 
inhibitory activity of protein hydrolysates prepared from three freshwater carps (Catla catla, Labeo rohita and Cirrhinus mrigala) using flavorzyme. International Journal of Food Science and Technology, 49: 1344-1350.

Elavarasan, K., Naveen Kumar, V and Shamasundar, B. A. 2014. Antioxidant and functional properties of fish protein hydrolysates from fresh water carp (Catla catla) as influenced by the nature of enzyme. Journal of Food Processing and Preservation, 38(3): 1207-1214.

FAO. 2014. State of world fisheries and aquaculture. Food and Agricultural Organization of the United Nations. Rome.

Gajanan, P.G., Elavarasan, K.,and Shamasundar, B. A. 2016. Bioactive and functional properties of protein hydrolysates from fish frame processing waste using plant proteases. Environmental Science and Pollution Research, 23(24): 24901-24911.

Hou, H., Li, B., Zhao, X., Zhang, Z.H. and Li, P.L. 2011. Optimization of Enzymatic Hydrolysis of Alaska Pollock Frame for Preparing Protein hydrolysate. Food Research International, 38: 45-50.

Hsu, K. C. 2010. Purification of antioxidative peptides prepared from enzymatic hydrolysates of tuna dark muscle byproduct. Food Chemistry, 122(1): 4248.

Je, J. Y., Park, P. J., Kwon, J. Y. and Kim, S. K. 2004. A novel angiotensin I converting enzyme inhibitory peptide from Alaska pollack (Theragra chalcogramma) frame protein hydrolysate. Journal of Agricultural and Food Chemistry, 52(26): 7842-7845.

Jung, W. K., Mendis, E., Je, J. Y., Park, P. J., Son, B. W., Kim, H. C. and Kim, S. K. 2006. Angiotensin I-converting enzyme inhibitory peptide from yellowfin sole
(Limanda aspera) frame protein and its antihypertensive effect in spontaneously hypertensive rats. Food Chemistry, 94(1): 26-32.

Kristinsson, H. G. and Rasco, B. A. 2000. Fish protein hydrolysates: production, biochemical, and functional properties. Critical Reviews in Food Science and Nutrition, 40(1): 43-81.

Kristinsson, H. G. and Rasco, B. A. 2002. Fish protein hydrolysates and their potential use in the food industry. Recent Advances in Marine Biotechnology, 7: 157-182.

Lempek, T. S., Martins, V. G. and Prentice, C. 2007. Rheology of surimi-based products from fatty fish underutilized by the industry: Argentine croaker (Umbrina canosai). Journal of Aquatic Food Product Technology, 16(4): 27-44.

Miller, R. and Groninger, H. S. 1976. Functional Properties of enzyme modified acylated fish protein derivatives. Journal of Food Science, 41(2): 268-272.

Naqash, S. Y. and Nazeer, R. A. 2013. Antioxidant and functional properties of protein hydrolysates from pink perch (Nemipterus japonicus) muscle. Journal of Food Science and Technology, 50(5): 972-978.

Neklyudov, A. D., Ivankin, A. N. and Berdutina, A. V. 2000. Properties and uses of protein hydrolysates (Review). Applied Biochemistry and Microbiology, 36(5): 452-459.

Nesse, K. O., Nagalakshmi, A. P., Marimuthu, P. and Singh, M. (2011). Efficacy of a fish protein hydrolysate in malnourished children. Indian Journal of Clinical Biochemistry, 26(4): 360365.

Ovissipour, $\quad$ M., $\quad$ Taghiof, $\quad$ M., Motamedzadegan, A., Rasco, B. and Molla, A. E. (2009). Optimization of enzymatic hydrolysis of visceral waste 
proteins of beluga sturgeon Huso huso using Alcalase. International Aquatic Research, 1(1): 31-38.

Rebeca, B. D., Pena- Vera, M. T. and Diaz- Castaneda, M. 1991. Production of fish protein hydrolysates with bacterial proteases; yield and nutritional value. Journal of Food Science, 56(2): 309-314.

Sathivel, S., Bechtel, P. J., Babbitt, J., Prinyawiwatkul, W., Negulescu, I. I. and Reppond, K. D. 2004. Properties of protein powders from arrowtooth flounder (Atheresthes stomias) and herring (Clupea harengus) byproducts. Journal of Agricultural and Food Chemistry, 52(16): 5040-5046.

See, S. F., Hoo, L. L. and Babji, A. S. 2011. Optimization of enzymatic hydrolysis of Salmon (Salmo salar) skin by Alcalase. International Food Research Journal, 18(4): 1359-1365.

Souissi, N., Bougatef, A., Triki-Ellouz, Y. and Nasri, M. 2007. Biochemical and functional properties of sardinella (Sardinella aurita) by-product hydrolysates. Food Technology and
Biotechnology, 45(2): 187-194.

Tanuja, S., Viji, P., Zynudheen, A. A. and Joshy, C. 2012. Composition, functional properties and antioxidative activity of hydrolysates prepared from the frame meat of striped catfish (Pangasianodon hypophthalmus). Egyptian Journal of Biology, 14(1): 27-35.

Venugopal, V. 2008. Marine products for healthcare: functional and bioactive nutraceutical compounds from the ocean. CRC press.

Wasswa, J., Tang, J., Gu, X. H. and Yuan, X. Q. 2007. Influence of the extent of enzymatic hydrolysis on the functional properties of protein hydrolysate from grass carp (Ctenopharyngodon idella) skin. Food Chemistry, 104(4): 16981704.

Yasumatsu, K., Sawada, K., Moritaka, S., Misaki, M., Toda, J., Wada, T. and Ishii, K. 1972. Whipping and emulsifying properties of soybean products. Agricultural and Biological Chemistry, 36(5): 719-727.

\section{How to cite this article:}

Srikanya, A., K. Dhanapal, K. Sravani, K. Madhavi and Praveen Kumar, G. 2017. A Study on Optimization of Fish Protein Hydrolysate Preparation by Enzymatic Hydrolysis from Tilapia Fish Waste Mince. Int.J.Curr.Microbiol.App.Sci. 6(12): 3220-3229.

doi: https://doi.org/10.20546/ijcmas.2017.612.375 